\title{
A retrospective assessment of marine biodiversity: a critical analysis of integration and aggregation rules
}

\author{
Susanna Jernberg ${ }^{1 *}$, Henrik Nygård ${ }^{1}$, Ainars Aunins ${ }^{2}$, Antti Lappalainen ${ }^{3}$, Anna-Stiina Heiskanen ${ }^{1}$, Jens Olsson ${ }^{4}$, \\ Pirkko Kauppila ${ }^{1}$, Samuli Korpinen ${ }^{1}$, Kirsi Kostamo ${ }^{1}$ and Laura Uusitalo ${ }^{1}$ \\ ${ }^{1}$ Finnish Environment Institute, Marine Research Centre, Helsinki, Finland \\ ${ }^{2}$ University of Latvia, Department of Zoology and Animal Ecology, Riga, Latvia \\ ${ }^{3}$ Natural Resources Institute Finland, Helsinki, Finland \\ ${ }^{4}$ Swedish University of Agricultural Sciences, Department of Aquatic Resources, Institute of Coastal Research, \\ Sweden
}

\begin{abstract}
Oceans around the world are threatened by human pressures. Ecological indicators are useful tools in understanding complex systems and their changes caused by human pressures, and the information they offer is also needed for ecosystem-based management. Integrated assessments combine information produced by several indicators at different spatial scales and thus offer a more holistic view of the status of the ecosystem. In this study, we evaluate the integration of biodiversity indicators at different spatial scales in two study areas in the Baltic Sea: Gulf of Finland and Bothnian Sea. By producing time series of the indicators and integrated assessments, we study the historical changes in the overall marine biodiversity status, and the impact of data availability, indicator selection, and choice of spatial assessment units on the status assessment. The integrated assessments are produced using the Biodiversity Assessment Tool (BEAT 3.0) and following the procedure of the HELCOM integrated assessment of biodiversity. The analysis shows that the results of the integrated assessment depend strongly on which indicators are available for the assessment, and on the chosen spatial assessment units. While the integrated assessments are a strong communication tool, their interpretation needs to be accompanied by information of indicators to avoid misleading conclusions about the marine ecosystem status.
\end{abstract}

\section{Keywords}

Baltic Sea; indicators; integrated assessment

\section{Code availability}

Our study used the Biodiversity assessment tool BEAT 3.0 (Nygård et al., 2018). This tool is available online at: doi.org/10.5281/zenodo.1288315 (Murray \& Nygård, 2018). We modified some of the input files to fit in our study purposes, and the modified files and a brief documentation of our assessment process are available at: doi.org/10.5281/zenodo.3267051.

\author{
Correspondence: \\ Contact S. Jernberg at susanna.jernberg@ymparisto.fi
}

\section{Cite this article as:}

Jernberg, S., Nygård, H., Aunins, A., Lappalainen, A., Heiskanen, A.-S., Olsson, J., Kauppila, P., Korpinen, S., Kostamo, K. \& Uusitalo, L.

A retrospective assessment of marine biodiversity: a critical analysis of integration and aggregation rules

Socio-Environmental Systems Modelling, vol. 1, 16128, 2019, doi:10.18174/sesmo.2019a16128

This work is licensed under a Creative Commons Attribution-NonCommercial 4.0 International License. 


\section{Introduction}

Human pressures on marine environments are increasing worldwide, and the effects of fisheries, harmful substances, and loss of habitat have resulted in decreased biodiversity in the oceans (Halpern et al., 2015). Being dependent on viable ecosystems, extensive loss of biodiversity has evident effects also on the provisioning of ecosystem services and human health (Worm et al., 2006). Therefore the role of ecosystem-based management of marine environments has become crucial in achieving the sustainable management of the seas. This means that ecosystem structure and functioning is taken into account along with socio-economic values, when deciding the use and management of marine areas. Information about the marine ecosystem status is needed and the assessment of ecosystem status should be linked to the human pressures (Borja et al., 2016).

Ecological indicators have been developed in Europe under several EU directives which aim at attaining good status in marine or coastal ecosystems (EC, 2000, 2008). The indicators should be based on the effects of human pressures on the selected indicator elements and be evaluated against quantitative thresholds (Heiskanen et al., 2016; Queirós et al., 2016; Rossberg et al., 2017). Developing such indicators is, however, challenging and requires plenty of data which is rarely available in such amounts that the data would fully cover, for instance, the variability of the indicator (Teixeira et al., 2016). Other challenges with indicators are associated with spatial scales, comparability of assessment scales, the classification boundaries of indicator status, and their applicability across different marine regions (Van Hoey et al., 2010). Despite the challenges, a growing number of indicators have become available for European marine regions (e.g. www.helcom.fi/baltic-sea-trends, oap.ospar.org, www.medqsr.org).

The information offered by a single indicator is limited to a specific habitat type or certain pressure types while several indicators together have more information value and give a more holistic view of the ecosystem (Borja et al., 2016). There are, however, challenges in finding a common and comparable system to assess good environmental status (GES) for example in European scale: (1) The physiographic variation in the European seas is substantial: warm waters of the Mediterranean Sea, colder waters near the Arctic and low salinities and reduced water exchange in the Baltic Sea and Black Sea all create unique ecosystems; (2) there are many potential ways to integrate indicators (Borja et al., 2014); and (3) variability exists not only in the data available, but also across the developed indicators and relevant thresholds (Hummel et al. 2015).

There is a growing interest towards integrated marine ecosystems assessments, i.e. integrating indicators describing the state of the environment or impacts on marine environment such as nutrient loading. In addition, the EU Marine strategy framework directive (MSFD) requires assessment of the integrated status of the European marine regions based on a set of criteria and indicators determining the GES (EC, 2008). Thus, marine biodiversity assessments have been carried out twice under the Baltic Sea marine convention (HELCOM, 2010, 2018) and integrated ecosystem assessments have also been done in the context of International Council for the Exploration of the Sea (see for example Diekmann and Möllmann, 2010).

Comparison of integrated assessment results of different marine areas during one assessment period has shown the importance of careful indicator selection (Uusitalo et al., 2016). There are also differences between trends in ecosystem components of different marine areas as demonstrated in the temporal integrated assessment study by Olsson et al. (2015). Assessments piloted in the Baltic Sea (HELCOM, 2010, 2018) provide snapshots of the history of the Baltic Sea and show that one of the key benefits of the process is in helping to communicate the complex issues in a relatively simple way (Borja et al., 2014). Although trends of several ecosystem components are presented in the Baltic Marine Environment Protection Commission - Helsinki Commission (HELCOM) assessments, integrated status assessment using the selected indicators covers only the assessment period of six years at the time.

In this paper, we build an integrated, indicator based biodiversity assessment based on longer time series, and present trends in integrated biodiversity status in two study areas in the Baltic Sea (Gulf of Finland and Bothnian Sea). Bringing the retrospective view into the integrated assessment allows us to compare the assessment method with the underlying indicators. There is a number of ecological indicators developed in these regions to enable assessment of multiple trophic levels (HELCOM, 2018). We apply these indicators on long-term biological 
data sets and produce indicator time series. Based on these indicator time series we develop a retrospective integrated analysis of the regional biodiversity status using the revised HELCOM Biodiversity Assessment Tool (Nygård et al., 2018) that has been developed for the HELCOM holistic assessment context (HELCOM, 2017h). We aggregate the indicator data across the spatial HELCOM assessment units and also evaluate the effects of such aggregations. This allows us to critically evaluate the use of integration and aggregation rules in ecosystem assessments, which are a requirement of the EU MSFD (EC, 2017). To achieve this, we evaluated 1) the historical changes in the overall marine biodiversity status 2) how the availability of data and selection of the indicators influence the resulting integrated assessment, and 3) the effect of the choice of spatial scales in the indicator integration.

\section{Materials and methods}

\subsection{Study areas}

The Baltic Sea is a semi-enclosed and shallow brackish-water sea area with an average depth of $54 \mathrm{~m}$ and a maximum depth of $459 \mathrm{~m}$ (Kullenberg \& Jacobsen, 1981). The narrow Danish straights are the only connection between the Baltic Sea and the more saline waters of the North Sea. The restricted water exchange between these two sea areas in tandem with the large fresh-water supply from the catchment, cause both salinity stratification and a strong salinity gradient between the northern oligohaline ( 0.5 to $6 \mathrm{psu}$ ) waters and the southern polyhaline (20 to 29 psu) waters (Kullenberg \& Jacobsen, 1981). These features together with clear seasonality with thermal stratification, and a partial ice cover during winter act to limit the distribution and numbers of species in the Baltic Sea. In general, the number of species decreases when moving from south to north, with the exception of the Gulf of Finland where the shallow coastal areas, and especially River Neva basin, hold a variety of habitats and species (HELCOM, 2010, 2012).

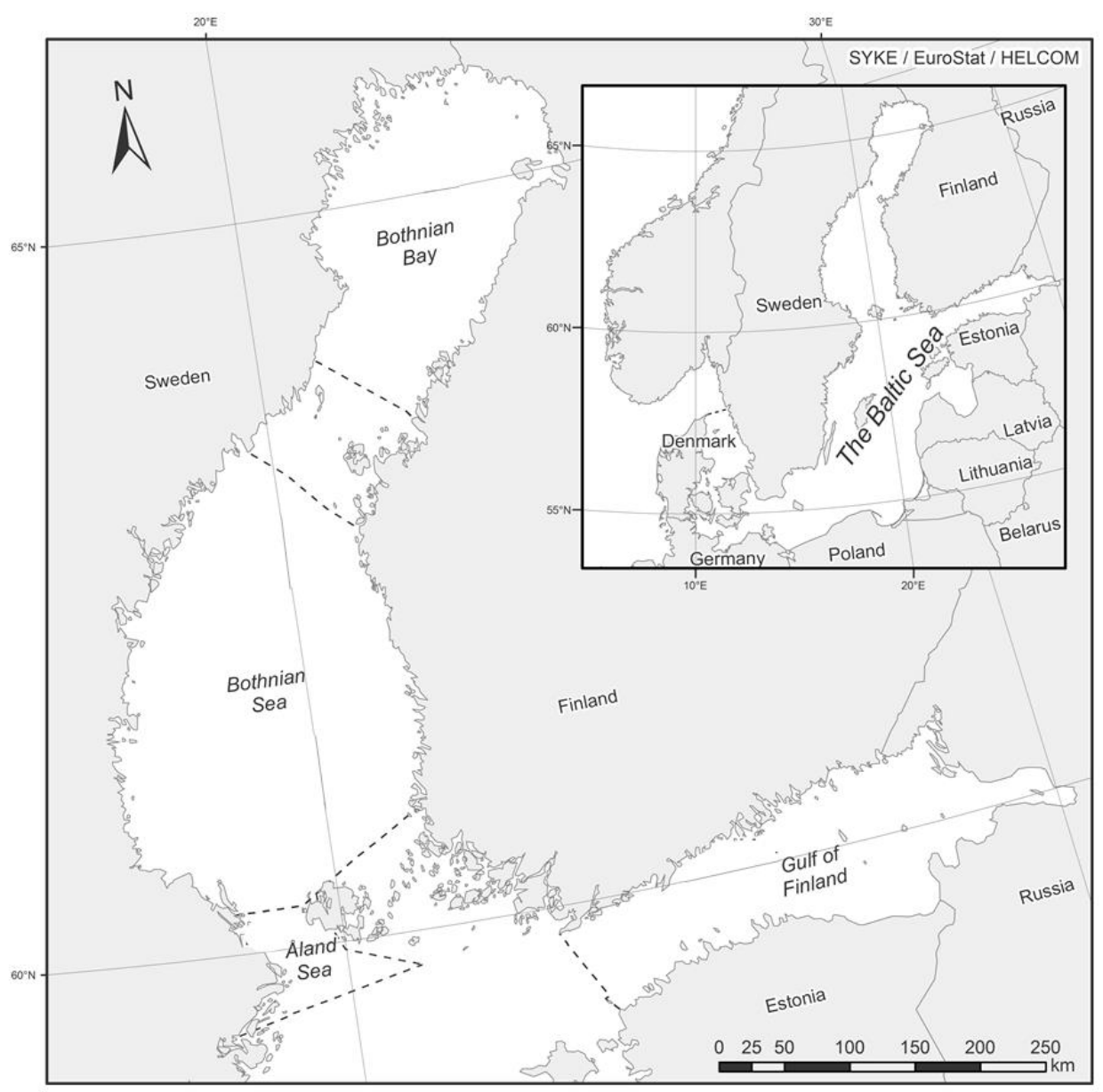

Figure 1: Map of the study areas: Bothnian Sea and Gulf of Finland. 
This study was conducted in two northern sub-basins of the Baltic Sea: the Gulf of Finland and the Bothnian Sea (Figure 1). The Gulf of Finland, being a relatively shallow basin with an average depth of $37 \mathrm{~m}$ and maximum depth of $123 \mathrm{~m}$ is a direct extension to the deep waters of the Baltic Proper (Kullenberg \& Jacobsen, 1981). The combined effects of the saline waters from the Baltic Proper and the large fresh-water influx from the River Neva leads to a decreasing salinity gradient from 7 in the western parts to the river waters of the Neva Bay in the easternmost part of the Gulf (HELCOM, 1996; Perttilä et al., 1995). The influence of the two different water masses causes strong salinity stratification at a depth of 60 to $70 \mathrm{~m}$ in the deepest part of the Gulf, from where the halocline weakens towards the east, strengthening again as the result of the River Neva waters (Leppäranta \& Myrberg, 2009). Due to the hydrographical features and strong nutrient loads from the watershed, the Gulf is very sensitive to eutrophication, which during recent decades has been expressed by intensified cyanobacterial blooms and hypoxic or anoxic bottom conditions (Conley et al., 2011; Kahru, et al., 2007; Vahtera et al., 2007) Additionally, the Gulf of Finland is one of the busiest maritime traffic routes in the world traversed by both passenger and cargo ships. This poses a major environmental risk to living organisms and their habitats, through exposure to oil spills and accidents (HELCOM, 2010).

The Bothnian Sea differs hydrographically from the Gulf of Finland; it is sheltered from the bulk of the Baltic Proper deep waters by a ridge formed by several underwater thresholds and by the shallowness of the Archipelago Sea (Håkansson et al., 1996). The Bothnian Sea is much deeper compared to the Gulf of Finland with an average depth of $66 \mathrm{~m}$ and maximum depth of $293 \mathrm{~m}$ but the salinity range is smaller, varying from 4 to 6 psu (Kullenberg \& Jacobsen, 1981). The basin has never suffered from near-bottom oxygen deficiency, due to its weak stratification and turnover of the whole water body extending to the seafloor in the spring and autumn. The intrinsic properties make the Bothnian Sea less sensitive to eutrophication than the Gulf of Finland. However, in recent years eutrophication has increased here too (Kuosa et al., 2017; Raateoja, 2013).

\subsection{Indicators}

The study includes all fully developed HELCOM CORE and Finnish MSFD biodiversity indicators for which data were available (Table 1). Some of the indicators represent abundance of one or few species, some describe the food web status more generally, and some are pure biodiversity indices such as the phytoplankton Shannon95 indicator. The indicators had varying geographical coverage; some were defined for all sea areas, some only for the open sea or coast (Table 1). For the coastal indicators, only the Finnish coast was evaluated.

To replicate the HELCOM holistic assessment of the Baltic Sea (HOLAS) assessment round (HELCOM, 2017g), which used a five-year assessment period at the time of writing this paper, we also used a five year period for our assessment. First, all indicators were calculated for each year. After that, a moving average of the past five years was calculated both to decrease noise and to imitate the situation in which an integrated assessment is conducted not yearly, but for a set of years. To reduce the effect of variability of a single year, the moving average was calculated only if there were at least three indicator values from the last five years. For coastal fish indicators, a moving average of eight years was used to cover the natural variability in indicator values (HELCOM, 2017a, 2017b) and hence to provide a sound view of current indicator values.

HELCOM integrated biodiversity report assesses the confidence of indicators based on four categories: accuracy of indicator classification, temporal coverage, spatial representation and methodological confidence (HELCOM, 2017h). The confidence is given in all of these categories for each indicator in all assessment units. The indicators included into this study were generally assessed to be reliable in terms of these four categories in the previous HOLAS assessment. Accuracy of classification is considered mostly moderate or high as the indicators are classified based on indicator specific thresholds (see indicator references in Table 1 for specific indicators). All indicators used in this study were already developed indicators and thus the data collection is done based on HELCOM or other methodology. HELCOM reports the overall confidence of the ecosystem components either being high or intermediate in the Bothnian Sea and Gulf of Finland, the seal status of Gulf of Finland being the only low one (HELCOM, 2017h). 
Table 1: Table shows the indicators which were included in this study, the ecosystem component they represent, their assessment units and available data series (BoS=Bothnian Sea, GoF=Gulf of Finland). The assessment unit means the unit for which the indicator is calculated before any integration is done. The aggregation rules of the spatial assessment units (SAUs) are presented in Figure 3 .

\begin{tabular}{|c|c|c|c|c|c|}
\hline Indicator & $\begin{array}{l}\text { Ecosystem } \\
\text { component }\end{array}$ & Assessment unit & $\begin{array}{l}\text { Available } \\
\text { data BoS }\end{array}$ & $\begin{array}{l}\text { Available } \\
\text { data GoF }\end{array}$ & $\begin{array}{l}\text { Indicator } \\
\text { description }\end{array}$ \\
\hline $\begin{array}{l}\text { Abundance of key coastal fish } \\
\text { species (HELCOM CORE) }\end{array}$ & Fish & $\begin{array}{l}\text { Coastal waters } \\
\text { /sub-basin }\end{array}$ & $1998-2015$ & $1998-2015$ & (HELCOM, 2017b) \\
\hline $\begin{array}{l}\text { Abundance of coastal fish key } \\
\text { functional groups (HELCOM CORE) }\end{array}$ & Fish & $\begin{array}{l}\text { Coastal waters / } \\
\text { sub-basin }\end{array}$ & $1998-2015$ & $1998-2015$ & (HELCOM, 2017a) \\
\hline $\begin{array}{l}\text { Abundance of salmon spawners and } \\
\text { smolt (HELCOM CORE) }\end{array}$ & Fish & Sub-basin & - & $2000-2015$ & (HELCOM, 2017c) \\
\hline $\begin{array}{l}\text { Abundance of sea trout spawners } \\
\text { and parr (HELCOM CORE) }\end{array}$ & Fish & Sub-basin & $1995-2016$ & $1989-2016$ & (HELCOM, 2015a) \\
\hline $\begin{array}{l}\text { Abundance of waterbirds in the } \\
\text { breeding season (HELCOM CORE) }\end{array}$ & Birds & Whole Baltic Sea & $1995-2015$ & $1995-2015$ & (HELCOM, 2017d) \\
\hline $\begin{array}{l}\text { Abundance of waterbirds in the } \\
\text { wintering season (HELCOM CORE) }\end{array}$ & Birds & Whole Baltic Sea & $1995-2015$ & $1995-2015$ & (HELCOM, 2017e) \\
\hline Brackish water benthic index (BBI) & Benthic habitat & Water body & $1977-2016$ & $1978-2016$ & (Perus et al., 2007) \\
\hline Chlorophyll - $a$ & Pelagic & Water body & $1976-2016$ & 1974- 2016 & (HELCOM, 2017f) \\
\hline Fucus growth depth & Benthic habitat & Water body & 2007-2015 & $2007-2015$ & (Aroviita, 2012) \\
\hline Grey seal abundance & Mammals & Whol Baltic Sea & $2003-2014$ & $2003-2014$ & (HELCOM, 2015b) \\
\hline Grey seal population growth & Mammals & Whole Baltic Sea & $2003-2014$ & $2003-2014$ & (HELCOM, 2015b) \\
\hline Herring spawning stock biomass & Fish & Sub-basin & $1974-2014$ & $1974-2014$ & (ICES, 2017) \\
\hline Phytoplankton Shannon95 & Pelagic & Water body & $1966-2016$ & $1968-2016$ & $\begin{array}{l}\text { (Uusitalo et al., } \\
\underline{2013)}\end{array}$ \\
\hline Sprat spawning stock biomass & Fish & Whole Baltic Sea & $1974-2014$ & $1974-2014$ & (ICES, 2017) \\
\hline White-tailed eagle productivity & Fish & Sea basin & $1970-2014$ & $1995-2014$ & (HELCOM, 2016) \\
\hline $\begin{array}{l}\text { Zooplankton mean size and total } \\
\text { stock (HELCOM CORE) }\end{array}$ & Pelagic & $\begin{array}{l}\text { Open sea / sea } \\
\text { basin }\end{array}$ & 1979-2015 & $1979-2015$ & (HELCOM, 2017i) \\
\hline
\end{tabular}

\section{$2.3 \quad$ BEAT tool}

\subsubsection{Integration and aggregation of indicators}

The assessment was done using the Biodiversity Assessment Tool (BEAT 3.0) (Nygård et al., 2018) which is also used in the biodiversity assessment of HELCOM HOLAS. The BEAT-tool is an open source software coded in R. BEAT uses five ecosystem components (following the MSFD) to express the status of biodiversity: birds, mammals, fish, benthic habitats and pelagic habitats. The ecosystem components are divided into species groups or broad habitat types and further to species or habitats, and finally to specific indicators (Fig. 2). Spatial aggregation follows the spatial assessment units (SAUs) outlined in the HELCOM Monitoring and Assessment Strategy (www.helcom.fi/action-areas/monitoring-and-assessment/monitoring-and-assessment-strategy). The highest SAU is the whole Baltic Sea, which is then divided into sub-basins (such as the Gulf of Finland and Bothnian Sea) (Fig. 3.). The sub-basins are further divided into coastal and open sea areas, and the coastal areas further into water types. We also added a fifth spatial level, water bodies, to the tool so as to be able to compare the effect of using different SAUs in the evaluation of indicators. 


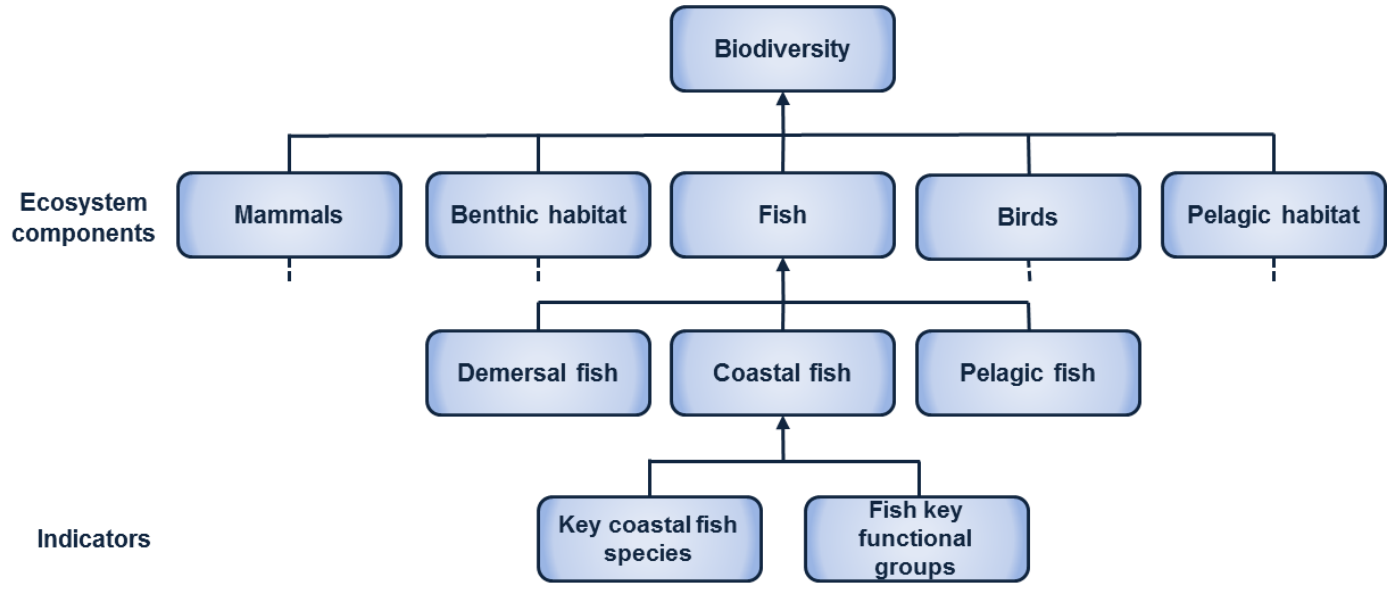

Figure 2: Integration rules of indicators with an example for fish indicators. The highest possible integration level would be biodiversity which is rarely used. Instead, the second level resolved to mammals, benthic habitat, fish, birds and pelagic habitat is the level that is used, for example, in HOLAS. All adjacent entries under the same ecosystem component have the same weight; for example demersal, coastal and pelagic fish each have a weighting of 0.333 , which together sum to 1.

In the BEAT-tool, weighting of indicators is balanced, so that each ecosystem component gets the same weight and within each ecosystem component all elements at the same level get the same weight; we only included elements that have indicators with a weighting assigned. This means that the highest level (Biodiversity) will have a weight of 1 , which is split among the ecosystem components represented with indicators. Indicators are assigned to the appropriate ecosystem component level (Table 1), and the allotted weight is then used in the integration of indicators upwards in the ecosystem component structure.

Different spatial assessment units are applied for different indicators depending on the ecology of the species in question (Table 1). In the spatial aggregation phase, the BEAT-tool evaluates the status in each SAU using all the indicators available for that SAU, starting from the smallest assessment units and working up the SAU hierarchy. The values are aggregated for the higher-level SAUs by area-based weighting. For example, the result for a water body that has a surface area of 254 square kilometers and the result of a water body with a surface area of 300 square kilometers will be aggregated to the higher level (water type) so that the water body with a slightly bigger surface area has a slightly higher weight.

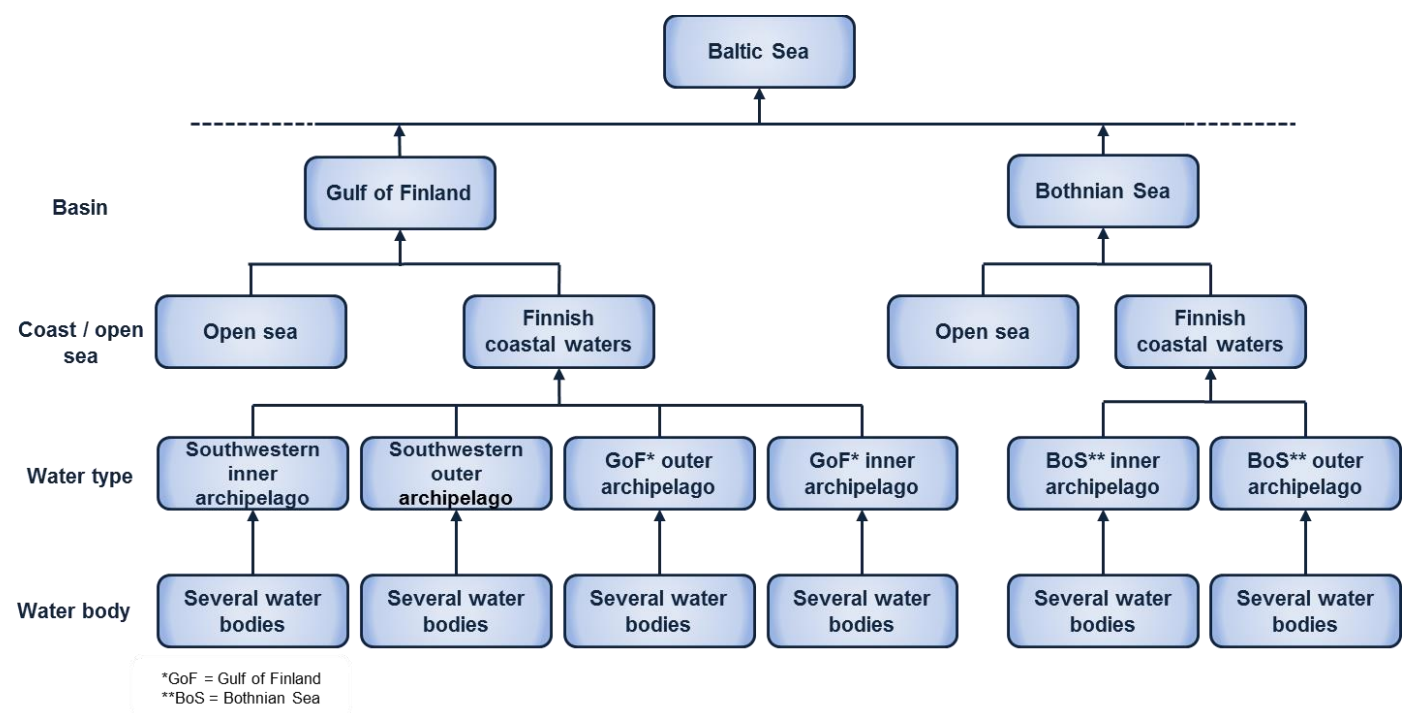

Figure 3: The spatial aggregation rules of the analysis are presented here. Some of the indicators are calculated to the water body level, some to water types etc. All boxes get their weight based on their surface area. All units that are on the same level and are aggregated up to the same unit, get a total weighted value of 1 . For example, the four boxes below the unit "Finnish coastal waters" in GoF (Southwestern inner archipelago, Southwestern outer archipelago, GoF outer archipelago and GoF inner archipelago) get a weight based on their surface area and they together sum up to 1 . In this study, the results were aggregated up to basin level (e.g. Gulf of Finland or Bothnian Sea). 
To allow comparison between the indicator results the BEAT-tool normalizes the indicator values to a scale between 0 and 1 placing the threshold value denoting the target value of good environmental state at 0.6. The normalized value is called biological quality ratio (BQR). The GES threshold at 0.6 is an in-built property of the BEAT tool. It stems from the EU's Water Framework Directive (WFD) (EC, 2000) classification, where 0.6 is set as the Good/Moderate border. As the WFD Good/Moderate border is also interpreted as the GES threshold in the MSFD, this threshold value was used in the scaling of indicators in BEAT.

In order to perform the normalization, minimum, maximum and GES threshold values are required for each indicator. These values have been set by the expert groups who have developed the indicators. These values vary depending on the data that the indicator is based on. If no minimum and maximum values were available, these were derived from the indicator dataset. Only after this, the normalization is done as follows: minimum value denotes 0 , maximum value 1 and the GES threshold value will be at 0.6. Trend-based indicators, e.g. indicators that are not associated with a point value (and so do not have a GES determined) but use the trend instead, cannot be used as such in BEAT. Consequently, in the case of these trend-based indicators, such as coastal key fish species in the Gulf of Finland, the method where the class is given based on the previous status assessment and the indicator trend during the current assessment period. The method is the same as that applied in HOLAS (HELCOM, 2017h). BEAT does not support time series assessment, so for the purposes of this work, the assessment was performed for each year separately, and the results were combined to produce time series.

\section{Results}

The results of this study demonstrate the impact of different integration and aggregation rules on the status assessment of the Gulf of Finland and the Bothnian Sea. The full results table is available online at: doi.org/10.5281/zenodo.3266843. In this paper, the impact of the following integration and aggregation rules are presented: the aggregation of a single ecosystem component from smaller to larger spatial assessment units (Figure 4), integration of multiple indicators inside one spatial assessment unit (Figure 5), integration of indicators to ecosystem component that are then spatially aggregated (Figure 6), and the highest integration of indicators and aggregation of spatial units that was possible to conduct with our datasets (Figure 7). The study shows that the aggregation across spatial assessment units results in loss of information, particularly the higher the level of aggregation. Also, the results are highly dependent on the available data; missing indicator data, especially from indicators covering large areas, may result in skewed interpretation of the biodiversity status.

\subsection{Effects of spatial aggregation}

The aggregation of a single ecosystem component from a smaller to a larger spatial assessment unit is presented using benthic indicators as an example (Figure 4). The benthic status of the water bodies (the lowest level of assessment units) belonging to four different water types in the Gulf of Finland are shown in Figure 4a. The status of water bodies are then aggregated to water types and the results are shown in Figure $4 \mathrm{~b}$.

There is a relatively high variance in the benthic status of different water bodies inside the water types, for instance in the year 2015 the benthic status of Gulf of Finland inner waters varies from 0.2 in some water bodies to 1 in other water bodies (Figure 4a). Some water bodies, such as Ss 029 and Ss 030, have been in good status for longer periods whereas others, such as Ss 006 and Ss 009, have been below GES. Different status developments can occur at relatively small spatial scales as shown in the benthic status of Gulf of Finland outer archipelago (Figure 4a).

The benthic status of water bodies are aggregated to different water types (Figure 4b). The southwest inner and outer archipelago seem to have slightly decreasing trend and the Gulf of Finland inner and outer waters show some improvement in the status of water types after 2005. The status development of the water type Gulf of Finland outer archipelago (Figure 4b) show the importance of data availability and the critical assessment of the available data. The aggregated status is above GES threshold during 1975-1992 but after that shows a steep drop in the status. This is because between 1975 and 1992 there are data only from one or two water bodies and when more water bodies and data are added in 1993, the status of the whole water type drops as the added water bodies have much lower status than the ones with longer data series. 


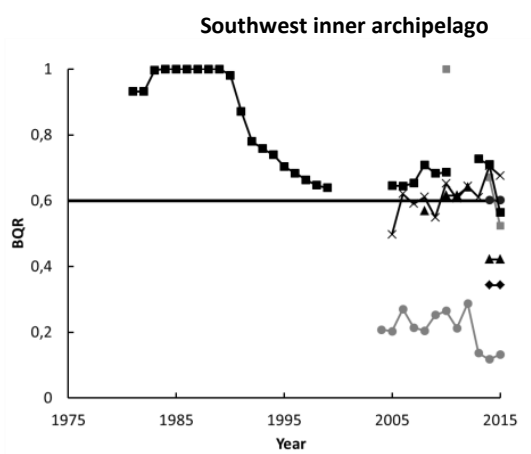

一GES

$\rightarrow-L 5003$

$\rightarrow$ Ls 006

$\rightarrow$ Ls 008

$\rightarrow-L 5009$

*Ls 010

$\rightarrow$ - 011
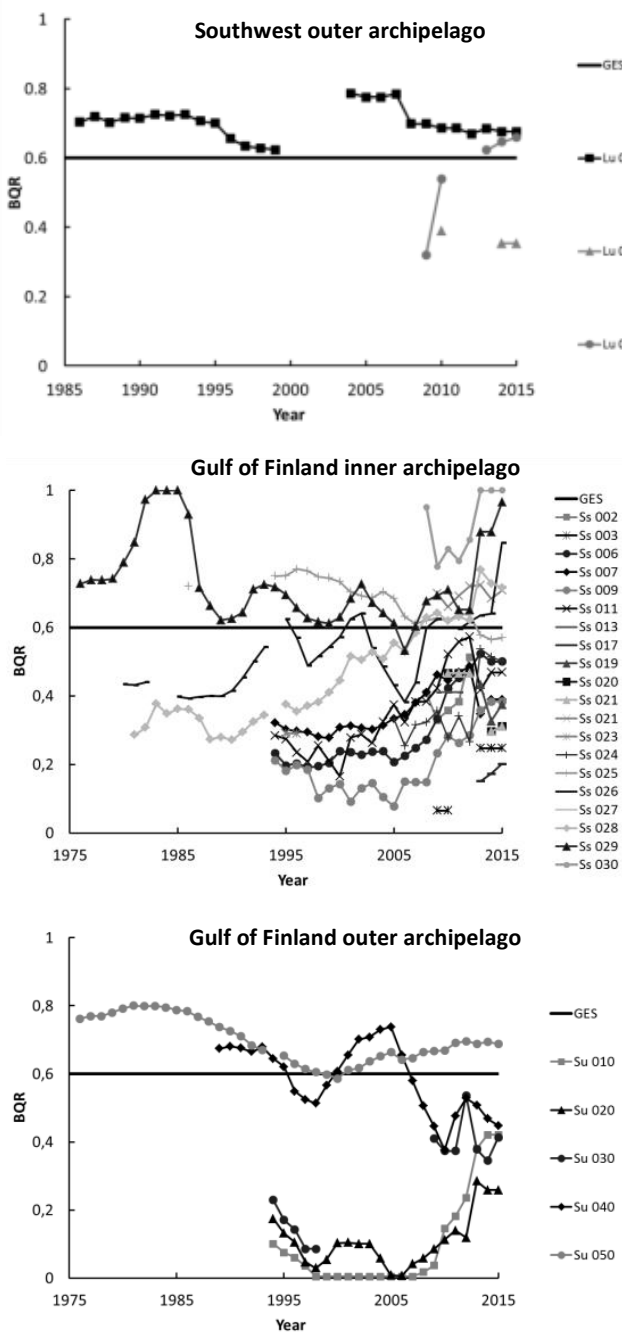

一GES

$\rightarrow-$ su 010

$\leftarrow$ su 020

$\rightarrow-54030$

$\rightarrow$ su 040

$\rightarrow-54050$

\section{c. All water types aggregated}

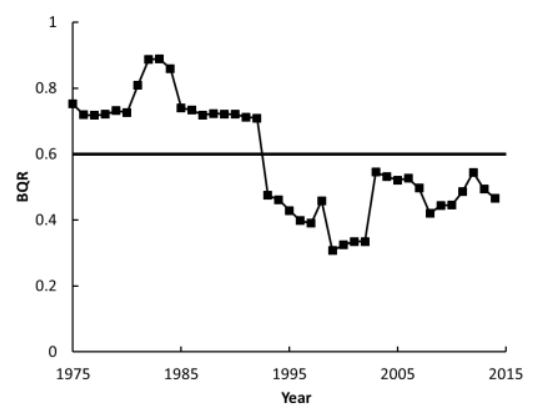

\section{b. Water types}
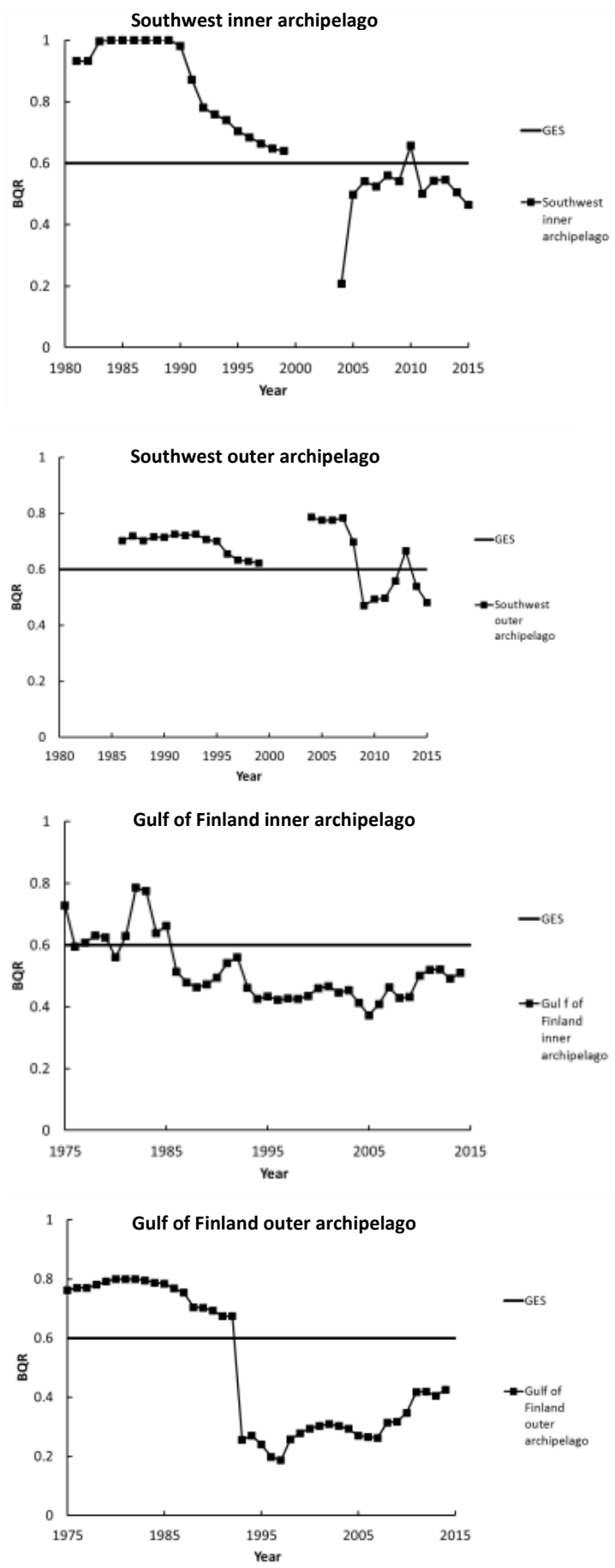

Figure 4: Spatial aggregation of one ecosystem component. This figure shows the status assessement results of benthic habitats at different spatial assessment units of the Gulf of Finland. Figure a shows the benthic status development at the smallest spatial units, water bodies (left column) and figure $b$ aggregates the benthic status results for four different water types (right column). In figure c, all of these water types are aggregated to produce a single value of benthic status in the Gulf of Finland Finnish coastal waters. The solid line in each figure marks the threshold of good environmental status (GES). 
In Figure 4c the aggregation is done further and the water types are aggregated to Finnish coastal waters (in the Gulf of Finland). In that figure, there is a dropdown in the status between years 2000 and 2003 due to the lack of data in two water types: southwestern inner and outer archipelago. These two water types show higher status than the other water types (Figure $4 \mathrm{~b}$ ), but as there is some data missing, the overall status assessment (Figure $4 \mathrm{~b}$ ) is done based on the two remaining water types that have lower status. This results in an overall lower status of the coastal waters. Thus, the result is highly dependent on which level of SAUs is used in the evaluation: the integration to higher level (Figure $4 b-c$ ) results in loss of information even in relatively small scale SAUs like the water types and coastal waters.

\subsection{Effects of indicator integration}

The integration of multiple indicators to biodiversity components is showcased using bird indicators as an example (Figure 5a-d). Birds are not aggregated spatially because they are calculated only for the whole Baltic Sea and no aggregation can be done, except for the white-tailed eagle, which was calculated for sub-basins and was then aggregated to the Baltic Sea level. Figure $5 \mathrm{a}$ demonstrates the status of bird functional groups belonging to the "abundance of waterbirds in the breeding season" indicator, and Figure $5 \mathrm{~b}$ shows the status of functional groups belonging to the "abundance of waterbirds in the wintering season" indicator. Some of the functional groups do not show any clear trend; the clearest trend is perhaps the trend of benthic feeding bird status showing a decreasing trend in both the wintering and the breeding bird indicators.

a. Breeding bird status in the Baltic Sea

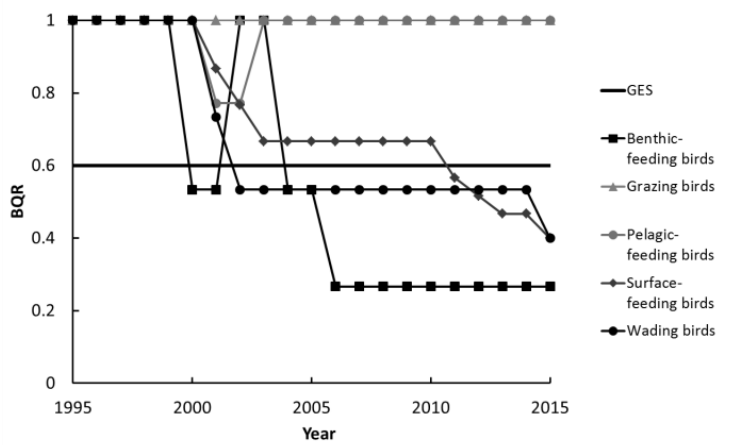

c. White-tailed eagle status in the Bothnian Sea and Gulf of Finland

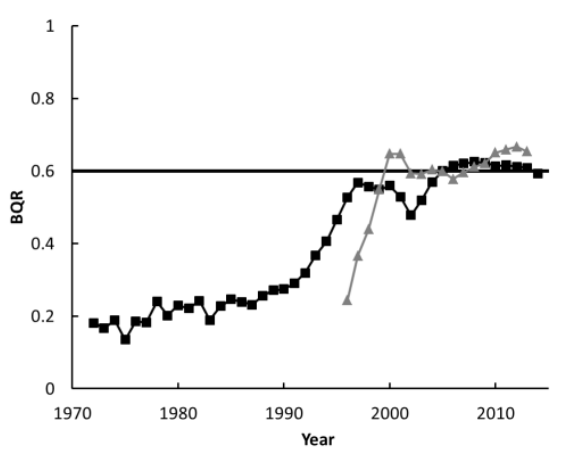

b. Wintering bird status in the Baltic Sea

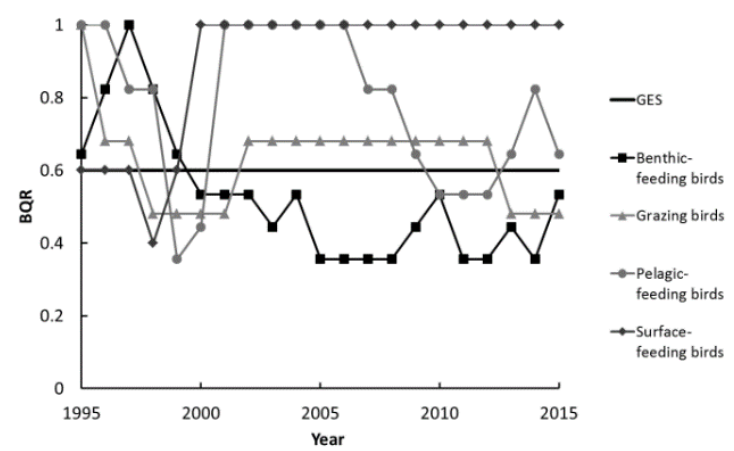

d. Bird status in the Baltic Sea

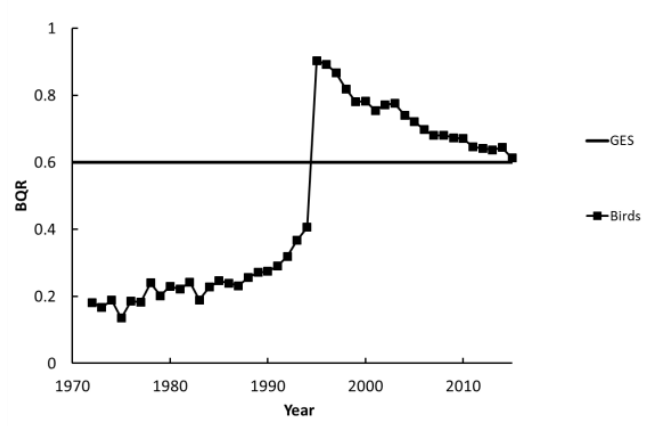

Figure 5: Integration of indicators to ecosystem component. This figure shows the integration of bird indicators in the Baltic Sea. Figure a shows the status of functional groups belonging to "abundance of waterbirds in the breeding season" indicator and figure $b$ the status of functional groups belonging to the "abundance of waterbirds in the wintering season" indicator. Figure $c$ shows the status development of white-tailed eagle in the Bothnian Sea and Gulf of Finland. In figure d, all these indicators are integrated to give a single value to bird status development in the Baltic Sea. The solid line in the figures marks the threshold of good environmental status (GES).

Figure $5 c$ shows the status of white-tailed eagle in the Bothnian Sea and Gulf of Finland and according to the indicator, the status has been improving in both basins. In Figure 5d, all the bird indicators are integrated to produce a single value for bird status in the Baltic Sea. As the white-tailed eagle indicator covers only the Gulf of Finland and Bothnian Sea areas, the weight of the indicator is smaller compared to other bird indicators that 
represent the whole Baltic Sea (Figure 5d). Between the years 1971 and 1995, the bird status is generated using only a single indicator (white-tailed eagle), as the data from other bird indicators does not cover that period. Therefore, the assessment of bird status before 1995 does not give information about the general trend in bird status, but only summarizes the status development of white-tailed eagle in the Bothnian Sea. After the year 1995, however, the integrated assessments show a decreasing trend in the bird status in the Baltic Sea.

Integration of indicators to ecosystem component level and their spatial aggregation is demonstrated using pelagic indicators (Figure 6). Figure 6a shows the status of pelagic indicators in the Gulf of Finland coastal waters and Figure $6 \mathrm{~b}$ shows the status of pelagic indicators in the Gulf of Finland open sea. In Figure $6 \mathrm{c}$, the coastal indicators are integrated to show the overall status of coastal pelagic habitat and the open sea indicator for pelagic habitat status is also presented (no integration was performed as there was only one indicator representing the open sea pelagic habitat status). In Figure $6 \mathrm{~d}$ both the coastal and open sea pelagic status are integrated together to give an overall pelagic habitat value for the Gulf of Finland.

a. Status of pelagic indicators in the Gulf of Finland coastal waters b. Status of pelagic indicators in the Gulf of Finland open sea
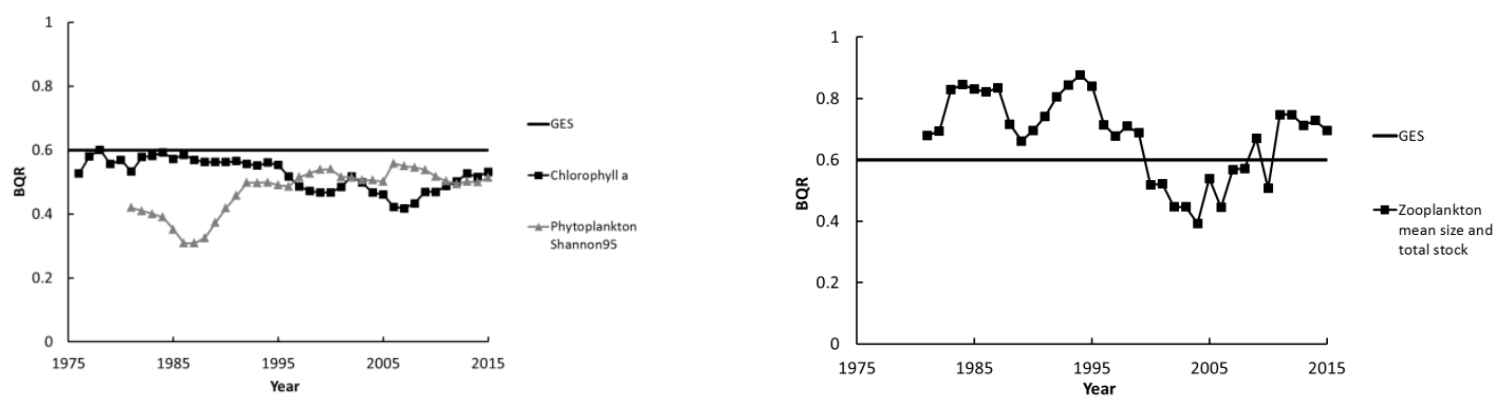

c. Status of coastal and open sea pelagic habitats in the Gulf of Finland d. Status of overall pelagic habitat in the Gulf of Finland
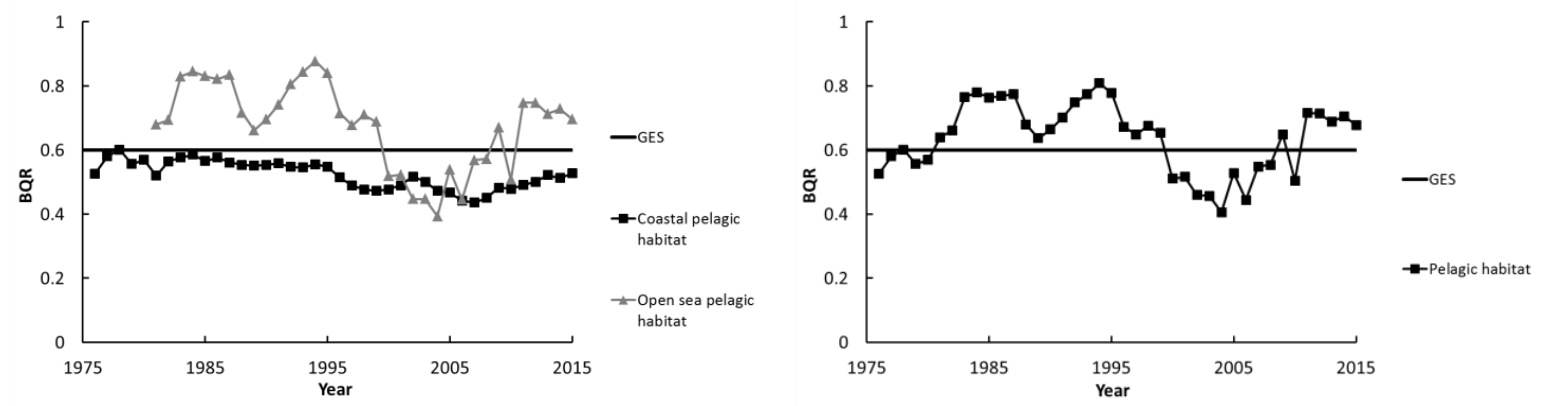

Figure 6: Integration of indicators to ecosystem components and aggregation to higher SAU. This figure shows the integration of pelagic indicators in the Baltic Sea. Figure a shows the status of pelagic indicators in the Gulf of Finland coastal waters, and figure $b$ shows the status of pelagic indicators in the Gulf of Finland open sea. In figure c, the coastal indicators are integrated to show the overall status of coastal pelagic habitat and the open sea indicator shows the overall open sea pelagic habitat status (no integration was performed as there was only one indicator representing the open sea pelagic habitat status). In figure $d$ both the coastal and open sea pelagic indicators are integrated together to give an overall pelagic habitat value for the Gulf of Finland. Solid line in the figures marks the threshold of good environmental status (GES).

A hypothetical situation where both the integration of indicators and the aggregation of SAUs have been done to the highest possible level within the limits of this study is presented in Figure 7. The status of biodiversity components in the Bothnian Sea and Gulf of Finland are presented in Figure 7a and 7b, respectively. The status values of ecosystem components in the Bothnian Sea are further integrated to get a single status value of biodiversity in the Bothnian Sea (Figure 7c). A similar integration was done with ecosystem components of the Gulf of Finland (Figure 7d). The ecosystem components that have indicators calculated for the open sea areas, such as fish and pelagic habitat, dominate the final value of biodiversity in both marine areas. In contrast, the benthic values that were only calculated for the coastal areas in this study, are not well reflected in the final value of biodiversity. This can be seen particularly well in Figure $7 \mathrm{~b}$ and $d$; in Figure $7 \mathrm{~b}$, the benthic habitat gets 
the lowest status values in years 2000-2003 but this is not reflected in the total biodiversity value of Gulf of Finland in the Figure 7d, where the status of biodiversity during years 2000-2003 is only slightly below GES.

a. Status of ecosystem components in the Bothnian Sea

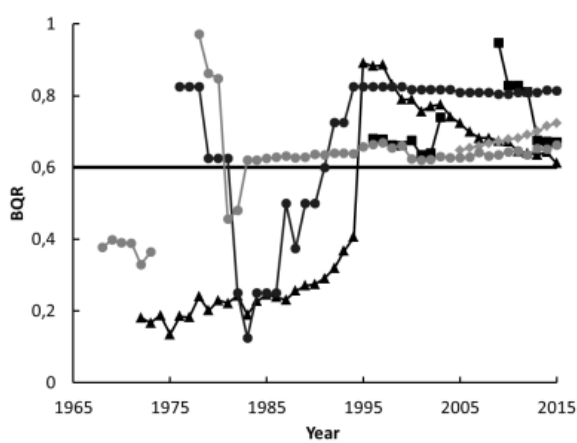

c. Status of biodiversity in the Bothnian Sea

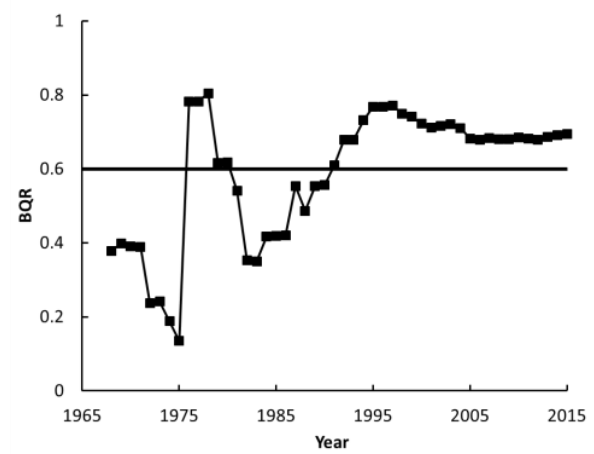

b. Status of ecosystem components in the Gulf of Finland

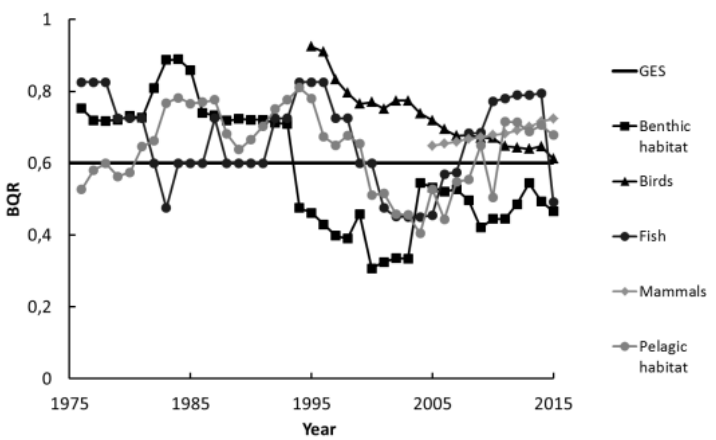

d. Status of biodiversity in the Gulf of Finland

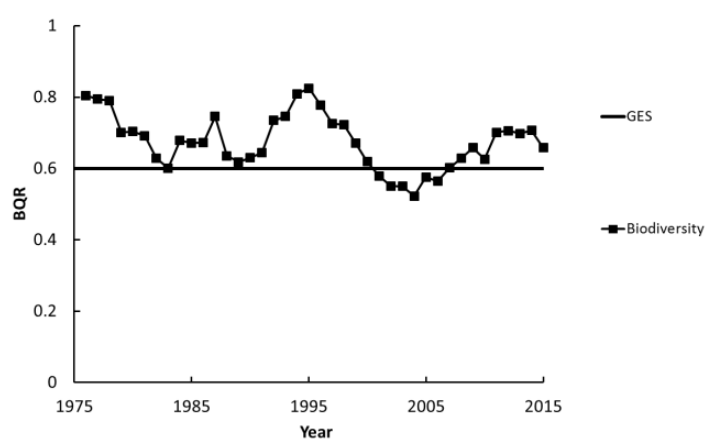

Figure 7: High level integration of indicators. These figures show an example of very high level integration of indicators and aggregation of SAUs. In figures a. and b., the indicators are integrated to ecosystem component level and the status is shown for a. the Bothnian Sea and b. Gulf of Finland. In figures c. and d. these ecosystem components are integrated further to produce an overall status value of biodiversity for c. Bothinan Sea and d. Gulf of Finland. Solid line in the figures marks the threshold of good environmental status (GES).

\section{Discussion and conclusions}

In this paper, we show temporal trends of integrated biodiversity status in the Gulf of Finland and the Bothnian Sea using HELCOM and Finnish national biodiversity indicators. Our objective was to evaluate how sensitive the assessment status is to indicator identities and spatial aggregation of results. The analysis shows that the results of the integrated assessment depend strongly on which indicators and how much data are available for the assessment, and on the level of spatial assessment units (SAU) that are used. With just few indicators available, the weight of a single indicator may become dominant. Also, the higher the level of SAU, the more the status results are prone to misinterpretations because the more data are being aggregated, the easier it is to miss data gaps even though they would have a significant impact on the final results. The implication of this is that the integrated results should be considered together with specific indicators and their confidence metadata, to avoid misleading conclusions about the changes in the environmental status.

As the environmental decisions under the EU marine strategies require integration and aggregation of marine indicators, our results can guide the method development towards more reliable integration and spatial aggregation. Based on our results, we recommend two solutions to avoid misinterpretation of data: (1) avoid integrated assessments with a few indicators only, because these increase the risk of erroneous conclusion, and (2) avoid indicator aggregations over spatial scales that have different drivers influencing the indicator results. The latter case is exemplified in Figure $4 \mathrm{~b}$, where the benthic status in Southwest inner and outer archipelago, compared to Gulf of Finland inner and outer archipelago, have contrasting trends due to different oxygen conditions in the areas (HELCOM, 2009). 
The risk of erroneous conclusion is exemplified by the bird status seen in Figure $5 d$, where the status suddenly jumps from 0.4 to 0.9 in year 1995 when a number of new indicators, all having high values, are included in the assessment. These changes are easy to spot from the time series presented in this work. However, for the purposes of the MSFD, the biodiversity status is reported to the EU every six years as a snapshot of current status, not as a time series (EC, 2008). Therefore, it is much more difficult to see if the changes in the assessment results are due to real change in the environmental status, an artefact in the indicator, SAU selection or availability.

No unified trend could be detected between ecosystem components as some of the indicators showed decreasing trends and others an increasing trend during the study period, which is in line with earlier findings by Uusitalo et al. (2016). The overall evaluation of biodiversity status is uncertain as indicators show very heterogenic trends and the assessment is sensitive to the number of indicators, also as shown in previous studies (Nemati et al., 2018; Ojaveer \& Eero, 2011; Probst \& Lynam, 2016).

Different integration rules have been evaluated and discussed in earlier studies (Borja et al., 2014; Ojaveer \& Eero, 2011). Some rules, such as one-out-all-out (OOAO) where the overall status is assigned based on the indicator with the lowest status, have been criticized for easily biasing the assessment to a poor status (Borja et al., 2014; Borja \& Rodríguez, 2010; Moe et al., 2015). Generally, the status assessment of the marine environment is sensitive to the selection of indicators and the chosen integration rules as the marine environment is affected by multiple pressures (Ojaveer \& Eero, 2011). The European Union has not yet specified the actual rules for integration in the MSFD, but the European Commission's Decision on GES criteria requests this and such development is already in this year's work programme (EC, 2017).

In BEAT, the spatial aggregation steps weight the SAUs according to their surface area. In general, averaging is prone to missing the bad status of some habitats which can lead to a situation where proper management actions are not taken but can still be considered better than some other aggregation methods (Borja et al., 2014). The problem is culminated when a single indicator defined to a larger SAU has much more weight than a high number of indicators defined for a smaller SAU; e.g. the only indicator defined for a large open sea pelagic habitat might end up in having many times the weight of multiple indicators that are defined for the coastal pelagic habitats (Figure 7). Coastal areas are much smaller compared to larger open sea areas and thus their status assessment will get lost in an integration that is done based on surface area alone. This must be understood and clearly communicated to the stakeholders and decision-makers, or an alternative weighting scheme could be considered. As the integration of indicators is not done to the biodiversity level in HOLAS, Figures 7a-d are just theoretical examples of how the biodiversity status would look like in the Bothnian Sea and Gulf of Finland. Here the same bias towards larger areas is dominating the status assessment of the whole biodiversity. At the moment, for example in HOLAS, coastal and open sea areas are considered separately (HELCOM, 2018), and based on our results, this is a wise decision.

The indicator identity and quality influence the assessment outcome. Recently, methods to test indicator sensitivity and specificity have been developed to ensure indicator quality (Chuševè et al., 2016; Jernberg et al., 2017; Queirós et al., 2016). The indicator identity, however, means that indicators may leave many important ecosystem aspects or components out. The benthic habitat status consists mainly of one single indicator (BBI) as the Fucus growth depth indicator results are only available for years 2010-2015. Many important habitats such seagrass meadows and mussel beds, that are key habitats in the Baltic Sea, are not covered by the current assessments. Therefore, the benthic status assessment basically reports the status of soft bottom habitats leaving out many other important habitats sustaining high biodiversity in the shallow photic coastal zones. Also when considering the whole assessment, the higher levels of the food-web are generally overrepresented in the indicators, fish alone having 6 out of 15 indicators, whereas smaller planktonic organisms are only covered by 3 of the indicators. And even from these indicators, it can be debated whether the chlorophyll $a$ is a biodiversity indicator at all. It is, however, included in the HELCOM integrated biodiversity assessment (HELCOM, 2017h), as it provides information about the biomass of the phytoplankton community. There are no indicators representing the bacteria and virus communities, and indicators describing their diversity are very scarce in general (Teixeira et al., 2016). Their role in the ecosystem is enormous, however, and efforts could be made to include them in the biodiversity assessments (Sarmento et al., 2010).

In conclusion, our study showed that integrating the indicators and aggregating them spatially may result in erroneous messages and, by definition, leads to loss of information. However, as the integrations are required 
by high-level policy-decisions in EU, the main focus should be on the communication of the overall status. Therefore we argue that the indicator integration should be done only across areas that have similar drivers of change (e.g. anthropogenic pressures, oceanographic characteristics). The Baltic Sea assessment units are a step to right direction. Also, it should be noted that the current indicator datasets have gaps regarding, e.g., important habitats which lead to biased integration and increased risk of miscommunication. Thus, our results support the conclusion that the communication of the biodiversity status should not be reduced to single outcomes but it should be hierarchical showing (1) indicators presenting status against GES thresholds and change in response to anthropogenic drivers and mitigation measures, and (2) easily communicable integrated status that give the overall state on the level that does not miss the correct message.

\section{Acknowledgments}

This study was partly funded by Maj and Tor Nessling foundation (Grant No. 201600194 and 201700022) and by BONUS BLUEWEBS project which has received funding from BONUS (Art 185), funded jointly by the EU and the Academy of Finland. We also want to than Heikki Lokki, Tapani Pakarinen and Ari Saura for offering data.

\section{References}

Aroviita J., Hellsten S., Jyväsjärvi J., Järvenpää L., Järvinen M., Karjalainen S.M., Kauppila P., Keto A., Kuoppala M., Manni K., Mannio J., Mitikka S., Olin M., Perus J., Pilke A., Rask M., Riihimäki J., Ruuskanen A., Siimes K., Sutela T., Vehanen T., Vuori K-M. (2012). Ohje pintavesien ekologisen ja kemiallisen tilan luokitteluun vuosille 2012-2013 - päivitetyt arviointiperusteet ja niiden soveltaminen. Ympäristöhalinnon ohjeita 7 [In Finnish].

Borja A., Elliott M., Andersen J.H., Berg T., Carstensen J., Halpern B.S., Heiskanen A.-S., Korpinen S., Lowndes J.S.S., Martin G. \& Rodriguez-Ezpeleta N.. (2016). Overview of integrative assessment of marine systems: the Ecosystem Approach in practice. Frontiers in Marine Science, 3. doi: 10.3389/fmars.2016.00020

Borja A., Prins T.C., Simboura N., Andersen J.H., Berg T., Marques J.-C., Neto J.M., Papadopoulou N., Reker J., Teixeira H. \& Uusitalo L. (2014). Tales from a thousand and one ways to integrate marine ecosystem components when assessing the environmental status. Frontiers in Marine Science, 1(72). doi: 10.3389/fmars.2014.00072

Borja A. \& Rodríguez J.G.. (2010). Problems associated with the 'one-out, all-out'principle, when using multiple ecosystem components in assessing the ecological status of marine waters. Marine Pollution Bulletin, 60(8), 1143-1146.

Chuševè R., Nygård H., Vaičiūtè D., Daunys D. \& Zaiko A. (2016). Application of signal detection theory approach for setting thresholds in benthic quality assessments. Ecological Indicators, 60, 420-427. doi: http://dx.doi.org/10.1016/j.ecolind.2015.07.018

Conley D.J., Carstensen J., Aigars J., Axe P., Bonsdorff E., Eremina T., Haahti B.-M., Humborg C., Jonsson P., Kotta J., Lännegren C., Larsson U., Maximov A., Medina M.R., Lysiak-Pastuszak E., Remeikaitė-Nikienè N., Walve J., Wilhelms S. \& Zillén L. (2011). Hypoxia Is Increasing in the Coastal Zone of the Baltic Sea. Environmental Science \& Technology, 45(16), 6777-6783. doi: 10.1021/es201212r

Diekmann R., \& Möllmann C. (Eds.). (2010). Integrated ecosystem assessments of seven Baltic Sea areas covering the last three decades. ICES Cooperative Research Report No. 302.

EC. (2000). Directive 2000/60/EC of the European Parliament and of the Council of 23 October 2000 establishing a framework for Community action in the field of water policy. (OJ L 327, 22.12.2000, pp. 1-73).

EC. (2008). Directive 2008/56/EC of the European Praliament and of the Council establishing a framework for community action in the field of marien environmental policy (Marine Strategy Framework Directive). Official Journal of European Union L232, 12-24.

EC. (2017). COMMISSION DECISION (EU) 2017/848 of 17 May 2017 laying down criteria and methodological standards on good environmental status of marine waters and specifications and standardised methods for monitoring and assessment, and repealing Decision 2010/477/EU. Official Journal of the European Union L125/43.

Halpern B.S., Frazier M., Potapenko J., Casey K.S., Koenig K., Longo C., Lowndes J.S., Rockwood R.C., Selig E.R., Selkoe K.A. \& Walbridge S. (2015). Spatial and temporal changes in cumulative human impacts on the world's ocean. 6, 7615. doi: 10.1038/ncomms8615

Heiskanen A.-S., Berg T., Uusitalo L., Teixeira H., Bruhn A., Krause-Jensen D., Lynam C.P., Rossberg A.G., Korpinen S., Uyarra M.C. \& Borja A. (2016). Biodiversity in Marine Ecosystems-European Developments toward Robust Assessments. Frontiers in Marine Science, 3(184). doi: 10.3389/fmars.2016.00184

HELCOM. (1996). Third periodic assessment of the state of the marine environment in the Baltic Sea 1989-1993. Backgroun document. In: Baltic Sea environ. Proc. No. 64B, 252 p.

HELCOM. (2009). Eutrophication in the Baltic Sea-an Integrated Thematic Assessment of the Effects of Nutrient Enrichment and Eutrophication in the Baltic Sea Region. Paper presented at the Balt Sea Environ Proc.

HELCOM. (2010). Ecosystem health of the Baltic Sea: HELCOM Initial Holistic Assessment. Baltic Sea Environment Proceedings, 122. 
HELCOM. (2012). Checklist of Baltic Sea Macro-species. Baltic Sea. Environment Proceedings No. 130.

HELCOM. (2015a). Abundance of sea trout spawners and parr. HELCOM core indicator report. Online. [18/02/2018], http://www.helcom.fi/Core\%20Indicators/Abundance\%20of\%20sea\%20trout\%20spawners\%20and\%20parr_HELC OM\%20core\%20indicator\%202015_web\%20version.pdf.

HELCOM. (2015b). Population trends and abundance of seals. HELCOM core indicator report. Online. [18/12/2017], http://www.helcom.fi/baltic-sea-trends/indicators/population-trends-and-abundance-of-seals/.

HELCOM. (2016). White-tailed eagle productivity. HELCOM core indicator report. Online. [16/01/2017], http://www.helcom.fi/baltic-sea-trends/indicators.

HELCOM. (2017a). Abundance of coastal fish key functional groups. HELCOM core indicator report. Online. [18/02/2018], http://www.helcom.fi/Core\%20Indicators/Abundance\%20of\%20coastal\%20fish\%20key\%20functional\%20groups_H ELCOM\%20core\%20indicator\%20-\%20HOLAS\%20II\%20component.pdf.

HELCOM. (2017b). Abundance of coastal fish key species. HELCOM core indicator report. Online. [18/02/2018], http://www.helcom.fi/Core\%20Indicators/Abundance\%20of\%20key\%20coastal\%20fish\%20species_HELCOM\%20co re\%20indicator-HOLAS\%20II\%20component.pdf.

HELCOM. (2017c). Abundance of salmon spawners and smolt. HELCOM core indicator report. Online. [18/02/2018], http://www.helcom.fi/Core\%20Indicators/Abundance\%20of\%20salmon\%20spawners\%20and\%20smolt_HELCOM\% 20core\%20indicator\%20-\%20HOLAS\%20II\%20component.pdf.

HELCOM. (2017d). Abundance of waterbirds in the breeding season. HELCOM core indicator report. Online. [18/02/2018], http://www.helcom.fi/Core\%2OIndicators/Abundance\%20of\%20waterbirds\%20in\%20breeding\%20season_HELCO M\%20core\%20indicator\%20-\%20HOLAS\%20II\%20component.pdf.

HELCOM. (2017e). Abundance waterbirds in the wintering season. HELCOM core indicator report. Online. [18/02/2018], http://www.helcom.fi/Core\%20Indicators/Abundance\%20of\%20waterbirds\%20in\%20wintering\%20season_HELCO M\%20core\%20indicator\%20-\%20HOLAS\%20II\%20component.pdf.

HELCOM. (2017f). Chlorophyll a. HELCOM core indicator report. Online. [24/04/2018], http://www.helcom.fi/Core\%20Indicators/Chlorophyll\%20a\%20-

\%20updated\%20core\%20indicator\%20report_HOLAS\%20II\%20component.pdf.

HELCOM. (2017g). First version of the 'State of the Baltic Sea' report - June 2017 - to be updated in 2018. Available at: http://stateofthebalticsea.helcom.fi.

HELCOM. (2017h). The integrated assessment of biodiversity - supplementary report to the first version of the 'State of the Baltic Sea' report 2017. Available at: http://stateofthebalticsea.helcom.fi/about-helcom-and-theassessment/downloads-and-data/.

HELCOM. (2017i). Zooplankton mean size and total stock. HELCOM core indicator report. Online. [24/04/2018], http://www.helcom.fi/Core\%20Indicators/Zooplankton\%20mean\%20size\%20and\%20total\%20stock_HELCOM\%20c ore\%20indicator\%20-\%20HOLAS\%20II\%20component.pdf.

HELCOM. (2018). State of the Baltic Sea - Second HELCOM holistic assessment 2011-2016. Baltic Sea Environment Proceedings 155.

Håkansson B., Alenius P. \& Brydsten L. (1996). Physical environment in the Gulf of Bothnia. Ambio, 5-12.

ICES. (2017). Advice on fishing opportunities, catch, and effort, Baltic Sea Ecoregion. Available at: http://www.ices.dk/community/advisory-process/Pages/Latest-Advice.aspx.

Jernberg S., Lehtiniemi M. \& Uusitalo L. (2017). Evaluating zooplankton indicators using signal detection theory. Ecological Indicators, 77, 14-22. doi: https://doi.org/10.1016/j.ecolind.2017.01.038

Kahru M., Savchuk O. P., \& Elmgren R. (2007). Satellite measurements of cyanobacterial bloom frequency in the Baltic Sea: interannual and spatial variability. Marine Ecology Progress Series, 343, 15-23.

Kullenberg G. \& Jacobsen T. (1981). The Baltic Sea: an outline of its physical oceanography. Marine pollution bulletin, 12(6), 183-186.

Kuosa H., Fleming-Lehtinen V., Lehtinen S., Lehtiniemi M., Nygård H., Raateoja M., Raitaniemi J., Tuimala J., Uusitalo L. \& Suikkanen S. (2017). A retrospective view of the development of the Gulf of Bothnia ecosystem. Journal of Marine Systems, 167, 78-92. doi: http://doi.org/10.1016/j.jmarsys.2016.11.020

Leppäranta M., \& Myrberg K. (2009). Physical oceanography of the Baltic Sea. Springer, Chicester, UK, pp. 378.

Moe S.J., Lyche Solheim A., Soszka H., Gołub M., Hutorowicz A., Kolada A., Picińska-Fałtynowicz J. \& Białokoz W. (2015). Integrated assessment of ecological status and misclassification of lakes: The role of uncertainty and index combination rules. Ecological Indicators, 48, 605-615. doi: https://doi.org/10.1016/j.ecolind.2014.08.018

Murray C., \& Nygård H. (2018, June 13). NIVA-Denmark/BalticBOOST: BalticBOOST Integrated Biodiversity Assessment Tool (Version v1.0.1b). Zenodo. http://doi.org/10.5281/zenodo.1288315

Nemati H., Shokri M.R., Ramezanpour Z., Ebrahimi Pour G.H., Muxika I. \& Borja Á. (2018). Sensitivity of indicators matters when using aggregation methods to assess marine environmental status. Marine Pollution Bulletin, 128, 234-239. doi: https://doi.org/10.1016/j.marpolbul.2018.01.031

Nygård H., Murray C. , Andersen J. H. , Martin G. , Torn K., \& Korpinen S. (2018). BEAT 3.0 - a Tool for Integrated Biodiversity Assessments. Journal of Open Research Software, 6(1), 19. doi: http://doi.org/10.5334/jors.226

Ojaveer H. \& Eero M. (2011). Methodological Challenges in Assessing the Environmental Status of a Marine Ecosystem: Case Study of the Baltic Sea. PLOS ONE, 6(4), e19231. doi: 10.1371/journal.pone.0019231

Olsson J., Tomczak M.T., Ojaveer H., Gårdmark A., Põllumäe A., Müller-Karulis B., Ustups D., Dinesen G.E., Peltonen H., Putnis I., Szymanek L., Simm M., Heikinheimo O., Gasyukov P., Axe P. \& Bergström L. (2015). Temporal development of 
coastal ecosystems in the Baltic Sea over the past two decades. ICES Journal of Marine Science, 72(9), 2539-2548. doi: 10.1093/icesjms/fsv143

Perttilä M., Niemistö L. \& Mäkelä K. (1995). Distribution, development and total amounts of nutrients in the Gulf of Finland. Estuarine, coastal and shelf science, 41(3), 345-360.

Perus J., Bonsdorff E., Bäck S., Lax H.-G., Villnäs A. \& Westberg V. (2007). Zoobenthos as indicators of ecological status in coastal brackish waters: a comparative study from the Baltic Sea. AMBIO: A Journal of the Human Environment, $36(2), 250-256$.

Probst W.N., \& Lynam C.P. (2016). Integrated assessment results depend on aggregation method and framework structure - A case study within the European Marine Strategy Framework Directive. Ecological Indicators, 61, 871-881. doi: https://doi.org/10.1016/j.ecolind.2015.10.040

Queirós A.M., Strong J.A., Mazik K., Carstensen J., Bruun J., Somerfield P.J., Bruhn A., Ciavatta S., Flo E., Bizsel N., Özaydinli M., Chuševė R., Muxika I., Nygård H., Papadopoulou N., Pantazi M. \& Krause-Jensen D. (2016). An Objective Framework to Test the Quality of Candidate Indicators of Good Environmental Status. Frontiers in Marine Science, 3(73). doi: 10.3389/fmars.2016.00073

Raateoja M.. (2013). Deep-water oxygen conditions in the Bothnian Sea. Boreal Environment Research, 18, $235-249$.

Rossberg A.G., Uusitalo L., Berg T., Zaiko A., Chenuil A., Uyarra M.C., Borja A. \& Lynam C.P. (2017). Quantitative criteria for choosing targets and indicators for sustainable use of ecosystems. Ecological Indicators, 72, 215-224. doi: https://doi.org/10.1016/j.ecolind.2016.08.005

Sarmento H., Montoya J.M., Vázquez-Domínguez E., Vaqué D. \& Gasol J.M. (2010). Warming effects on marine microbial food web processes: how far can we go when it comes to predictions? Philosophical Transactions of the Royal Society B: Biological Sciences, 365(1549), 2137-2149.

Teixeira H., Berg T., Uusitalo L., Fürhaupter K., Heiskanen A.-S., Mazik K., Lynam C.P., Neville S., Rodriguez J.G., Papadopoulou N., Moncheva S., Churilova T., Kryvenko O., Krause-Jensen D., Zaiko A., Veríssimo H., Pantazi M., Carvalho S., Patrício J., Uyarra M.C. \& Borja À. (2016). A Catalogue of Marine Biodiversity Indicators. Frontiers in Marine Science, 3(207). doi: $10.3389 /$ fmars.2016.00207

Uusitalo L., Blanchet H., Andersen J., Beauchard O., Berg T., Bianchelli S., Cantafaro A., Carstensen J., Carugati L., Cochrane S., Danovaro R., Heiskanen A.-S., Karvinen V., Moncheva S., Murray C., Neto J., Nygård H., Pantazi M., Papadopoulou N., Simboura N., Srèbaliené G., Uyarra M. \& Borja A. (2016). Indicator-based assessment of marine biological diversity - lessons from 10 case studies across the European Seas. Frontiers in Marine Science, 3(159). doi: 10.3389/fmars.2016.00159

Uusitalo L., Fleming-Lehtinen V., Hällfors H., Jaanus A., Hällfors S. \& London L. (2013). A novel approach for estimating phytoplankton biodiversity. ICES Journal of Marine Science, 70(2), 408-417. doi: 10.1093/icesjms/fss198

Vahtera E., Conley D.J., Gustafsson B.G., Kuosa H., Pitkänen H., Savchuk O.P., Tamminen T., Viitasalo M., Voss M., Wasmund N. \& Wulff F. (2007). Internal Ecosystem Feedbacks Enhance Nitrogen-fixing Cyanobacteria Blooms and Complicate Management in the Baltic Sea. AMBIO: A Journal of the Human Environment, 36(2), 186-194. doi: 10.1579/00447447(2007)36[186:IEFENC]2.0.CO;2

Van Hoey G., Borja A., Birchenough S., Buhl-Mortensen L., Degraer S., Fleischer D., Kerckhof F., Magni P., Muxika I., Reiss H., Schröder A. \& Zettler M.L. (2010). The use of benthic indicators in Europe: From the Water Framework Directive to the Marine Strategy Framework Directive. Marine Pollution Bulletin, 60(12), 2187-2196. doi: https://doi.org/10.1016/j.marpolbul.2010.09.015

Worm B., Barbier E.B., Beaumont N., Duffy J.E., Folke C., Halpern B.S., Jackson J.B.C., Lotze H.K., Micheli F., Palumbi S.R., Sala E., Selkoe K.A., Stachowicz J.J. \& Watson R. (2006). Impacts of Biodiversity Loss on Ocean Ecosystem Services. Science, 314(5800), 787-790. doi: 10.1126/science.1132294 